\title{
Road Construction Equipment Management: A Case Study on Selected Industry
}

\author{
Samson Mekbib Atnaw \\ Faculty of Engineering Technology, Universiti Malaysia Pahang \\ Lebuhraya Tun Razak, 26300 Gambang, Kuantan, Pahang, Malaysia \\ mekbibsams@ump.edu.my \\ Lakhveer Singh \\ Faculty of Engineering Technology, Universiti Malaysia Pahang \\ Lebuhraya Tun Razak, 26300 Gambang, Kuantan, Pahang, Malaysia \\ Ftwi Yohaness Hagos \\ Faculty of Mechanical Engineering, Universiti Malaysia Pahang \\ 26600 Pekan, Kuantan, Pahang, \\ Malaysia \\ Abu Yousuf \\ Faculty of Engineering Technolog, Universiti Malaysia Pahang \\ Lebuhraya Tun Razak, 26300 Gambang, Kuantan, Pahang, Malaysia
}

\begin{abstract}
The major share of capital and equipment intensive operation goes to the road sector and the hydro - electric power projects. The construction sector in Ethiopia is developing at a fast rate and its capital budget is increasing from year to year. One of the reasons for this high growth is the number of new construction projects underway and those in the pipeline. In addition, the hydro-electric power projects the government has given a great emphasis to increase the current installed power of $780 \mathrm{Mw}$ to a total of 10,000Mw in the coming few years. These hydro-power projects are known for using a great deal of high investment heavy machineries. Therefore, the construction equipment management plays a great role in finalizing the projects with fewer budgets and no time over run. Considering the higher operation, maintenance and investment cost of construction equipment, it is important to have a carefully optimized decision making model that will help in the sizing and selection of the right combination of equipment for a given project. Even the rental versus purchase evaluation needs careful consideration of the project requirement and its duration. This study tries to analyze the existing situation taking a selected company as a case study with regard to construction equipment management. The study tries to cover the equipment management policy of the company, suppliers/manufacturers evaluation and selection criteria, types of purchase processes employed, as well as different make types and capacities of equipment owned by the company. Moreover, capacities of standard facilities available for the central maintenance workshop and replacement plan of equipment of the company in the coming five years will be investigated and commented on.
\end{abstract}

Index Terms-Construction equipment management Equipment management policy

\section{INTRODUCTION}

The construction sector in Ethiopia is developing at a fast rate and its capital budget is increasing from year to year. One of the reasons for this high growth in the number of new construction projects underway and those in the pipeline. The major share of capital and equipment intensive operation goes to the road sector and the hydro - electric power projects. For example the road sector development program 2006-2010 has a total budget of 43.2 billion Birr which includes strengthening of main roads, upgrading of existing main roads, upgrading feeder roads and rehabilitation of major roads to mention a few. And it is important to note that 60-70\% of road construction cost goes to the investment, rent and running cost of construction equipment. This gives construction equipment management a very special place in determining the development of the sector and the nation as a whole. Also in the hydro-electric power projects the government has given a great emphasis to increase the current installed power of $780 \mathrm{Mw}$ to a total of $10,000 \mathrm{Mw}$ in the coming few years. The major projects underway and in the pipe line include: Fincha- $100 \mathrm{MW}$, 
Gibe III project - on Omo - Gibe river $-1870 \mathrm{Mw}$ started in December 2006, Gibe Iv project - 2,400MW, Genale- Dawa - 600Mw, Grand Ethiopian Renaissance Dam - 6000 Mw started in March 2011.

These hydro-power projects are known for using a great deal of high investment heavy machineries. Therefore, the construction equipment management plays a great role in finalizing the projects with fewer budgets and no time over run. This will make sure the rapid growth of infrastructure and technological development in the country making it a better place for investment. Therefore, in this project the study of the construction equipment management in the road sector is considered as a model. It is believed that the study will be a model for other heavy construction projects like hydroelectric power plants, industrial site developments and sewer and water system construction.

The cost of the construction equipment is very high with most of the cases in the range of Br. 2-4 million (for hydraulic excavators, Dozers, Graders). The investment cost of the equipment's goes up to Br. 10 million if asphalt plant and crushing plants are considered. Therefore, it is important to have a carefully optimized decision making model that will help in the sizing and selection of the right combination of equipment's for a given project [1]. Even the rental versus purchase evaluation needs careful consideration of the project requirement and its duration. Operation is also another important dimension as it depends on the performance of machines plus operators. Therefore, the other difficulty is the skill and discipline of the operator and his/her motivation and interest in the job, expressed, in proper up-keep of machines. Lack of proper maintenance could also result in lower productivity and shorter life of construction equipment's [2-4].

The study tries to cover the equipment management policy of the company, suppliers/manufacturers evaluation and selection criteria, types of purchase processes employed, as well as different make types and capacities of equipment owned by the company. Moreover, capacities of standard facilities available for the central maintenance workshop and replacement plan of equipment of the company in the coming five years will be investigated and commented on. A detailed evaluation of the system will also be carried in the eye of a through literature survey, that is believed to inspire development of a standard approach for the equipment and maintenance management system of the organization and the construction sector as a whole.

\section{COMPANY BACKGROUND}

SS Construction is one of the leading companies capable of handling complex and challenging projects ranging from residential, warehouse and office complex buildings, road and bridge construction, and now have ventured in to realestate development. SS Construction was established in the 1980's as a sole proprietorship and later transformed into a private limited company.

Since its establishment, SS has been one of the front-runners in the development of the construction sector of Ethiopia. It started out with meager capital and lower class of professional register. Through hard work and capacity building, it has established itself as one of the leading construction companies with a strong financial capital, human resource and facilities. It is now operating as a class one general contractor.

\section{Completed Projects and Heavy Machinery Owned}

The completed building and road projects of the company and the respective project costs are summarized in Tables 1 and 2 respectively. The list of equipment's currently owned by the company and their total capital is shown in Table 3 . The data in Table 1 to 3 shows the companies active involvement in construction activities in the country and make it a good case study organization for investigating the status of construction equipment management in the country. 
Table 1: Completed building projects

\begin{tabular}{|c|c|c|c|}
\hline$\#$ & Description & \# of & Contract Value \\
\hline 1 & Roof maintenance and water- & 15 & $2,428,000.00$ \\
\hline 2 & Warehouse building and & 3 & $2,979,000.00$ \\
\hline 3 & Office Building & 8 & $95,420,000.00$ \\
\hline 4 & Class room and dormitory & 7 & $221,605,000.00$ \\
\hline 5 & Housing project & 1 & $15,889,000.00$ \\
\hline 6 & petroleum depot construction & 3 & $67,157,000.00$ \\
\hline 7 & Apartment building complex & 1 & $42,946,000.00$ \\
\hline 8 & Market building complex & 1 & $39,510,000.00$ \\
\hline \multicolumn{3}{|c|}{ Total Contract Value } & $\mathbf{4 7 8 , 9 3 4 , 0 0 0 . 0 0}$ \\
\hline
\end{tabular}

*ETB - Ethiopian Birr

Table 2: Completed Road Projects

\begin{tabular}{|c|c|c|}
\hline$\#$ & Description & Contract Value \\
\hline 1 & $100 \mathrm{Km}$ gravel with bridge and culvert & $27,154,085.00$ \\
\hline 2 & $21 \mathrm{Kms}$, turnkey design and & $14,275,575.00$ \\
\hline 3 & Ditto but 37 Kms & \\
\hline 4 & $72 \mathrm{Kms}$, gravel with bridge and culvert & $16,474,725.00$ \\
\hline 5 & $14 \mathrm{kms}$, compound double surface treatment & $23,509,030.00$ \\
\hline 6 & $51 \mathrm{~km}$ gravel road with bridges and culvert & $24,191,709.00$ \\
\hline 7 & $57 \mathrm{~km}$ gravel road with bridge and culvert & $74,355,676.00$ \\
\hline 8 & $2.3 \mathrm{~km}$ double lane asphalt concrete & $47,901,262.00$ \\
\hline \multicolumn{2}{|c|}{ Total Contract Value } & $\mathbf{2 5 1 , 0 6 8 , 0 7 7 . 0 0}$ \\
\hline
\end{tabular}

$$
\text { *ETB - Ethiopian Birr }
$$

Table 3: Types and brands of equipment and vehicles owned by the company

\begin{tabular}{|c|c|c|c|c|c|c|}
\hline$\#$ & Description & Make & Model & QTY & $\begin{array}{l}\text { Avg. } \\
\text { Price }\end{array}$ & Total Amount \\
\hline 1 & Dozer 305HP & CAT & D8R & 18 & $3,575,700$ & $64,362,600$ \\
\hline 2 & Dozer 302HP & $\begin{array}{c}\text { KOMAT } \\
\text { SU }\end{array}$ & D155A-5 & 1 & $2,848,295$ & $2,848,295$ \\
\hline 3 & Dozer $250 \mathrm{HP}$ & CAT & D7G & 1 & $2,621,750$ & $2,621,750$ \\
\hline 4 & Wheel Loader & VOLVO & L120C/E & 6 & $1,518,848$ & $9,113,088$ \\
\hline 5 & Wheel Loader & CAT & $938 \mathrm{~F}$ & 2 & $1,278,750$ & $2,557,500$ \\
\hline 6 & Wheel Loader & CAT & $966 \mathrm{G} / \mathrm{H}$ & 3 & $2,352,900$ & $7,058,700$ \\
\hline 7 & Wheel Loader & VOLVO & L90C & 1 & $1,175,000$ & $1,175,000$ \\
\hline 8 & Wheel Loader & SEM & ZL50G & 6 & 622,750 & $3,736,500$ \\
\hline 9 & $\begin{array}{c}\text { Chain } \\
\text { Excavator }\end{array}$ & CAT & 322BL & 1 & $1,800,000$ & $1,800,000$ \\
\hline 10 & $\begin{array}{c}\text { Chain } \\
\text { Excavator }\end{array}$ & $\begin{array}{c}\text { KOMAT } \\
\text { SU }\end{array}$ & PC220-7 & 4 & $1,246,718$ & $4,986,872$ \\
\hline 11 & $\begin{array}{l}\text { Chain } \\
\text { Excavator }\end{array}$ & $\begin{array}{c}\text { KOMAT } \\
\text { SU }\end{array}$ & РС $300-7$ & 5 & $1,931,110$ & $9,655,552$ \\
\hline 12 & $\begin{array}{l}\text { Wheel } \\
\text { Excavator }\end{array}$ & CAT & $\begin{array}{c}\text { M316C/ } \\
D\end{array}$ & 3 & $1,665,411$ & $4,996,234.08$ \\
\hline 13 & Motor Grader & CAT & $140 \mathrm{H}$ & 9 & $2,550,000$ & $22,950,000$ \\
\hline 14 & Motor Grader & CAT & $14 \mathrm{H}$ & 2 & $2,812,079$ & $5,624,159$ \\
\hline 15 & $\begin{array}{l}\text { Single Drum } \\
\text { Combactor }\end{array}$ & $\begin{array}{c}\text { DYNAPA } \\
\mathrm{C}\end{array}$ & $\begin{array}{c}\text { CA251D/ } \\
\text { PD }\end{array}$ & 4 & 512,420 & $2,049,680$ \\
\hline 16 & $\begin{array}{l}\text { Single Drum } \\
\text { Compactor }\end{array}$ & $\begin{array}{c}\text { DYNAPA } \\
C \\
\end{array}$ & CA600 & 8 & $1,120,000$ & $8,960,000$ \\
\hline 17 & $\begin{array}{c}\text { Genset } 160 \\
\text { TPC }\end{array}$ & FRANCE & MESTO & 2 & $\begin{array}{c}15,429,31 \\
1\end{array}$ & $30,858,622$ \\
\hline 18 & $\begin{array}{c}\text { Mobile Crane } \\
45 \text { Ton }\end{array}$ & JAPAN & K452 & 2 & $3,100,000$ & $6,200,000$ \\
\hline 19 & Tower Crane & $\begin{array}{c}\text { AUSTRI } \\
\text { A }\end{array}$ & $\begin{array}{c}\text { LIBHEE } \\
\mathrm{R}\end{array}$ & 1 & $2,278,461$ & $2,278,461$ \\
\hline \multicolumn{4}{|c|}{ Sub Total } & 78 & & $193,833,013$ \\
\hline
\end{tabular}




\section{FREQUENCY OF ACCIDENTS AND ASSOCIATED COST}

Taking data of the last 6 months the number of accidents observed is 18. Eleven of the accidents were recorded on Trucks (fuel trucks, water trucks and dam trucks) and 7 numbers of accidents were on small vehicles. The causes of most of the accidents were negligence and attitude problem of the operators. And the average cost of the accidents is estimated to be 65.000 per accident and 25,000 per accident. for trucks and vehicles respectively, with a total cost of accidents being over 890,000 in 6 months. Heavy machinery accidents were found to be rare in the company except some rare cases of accident during unloading of truck type excavators and loaders from the lowbed of trucks. To prevent such accidents it is recommended to increase the skill of operators and to provide skilled signal men to assist them during unloading.

\section{INVENTORY CONTROL AND SPARE PARTS MANAGEMENT}

It is difficult and very costly to give equal attention to all the items of inventory. $\mathrm{ABC}$ analysis is meant for relative inventory control in which maximum attention can be given to items which consume more money and a fair attention can be given to medium value items, while the attention to medium value items will be reduced to routine procedure only [5-7].

\section{A. Policies for A items}

1. Since these items account for over $70 \%$ of the total value of spare parts in the company, hence they should be ordered more frequently, but in small quintiles, in order to reduce capital locked up at any time.

2. The requirement of such items must be planned in advance for expected future consumption, so that only required quantities arrive a little before they are required for consumption.

3. Purchase of A items should be looked into by the top executives in purchasing department (and with the involvement of technical personnel when needed).

4. Since A items should be stocked as minimum as possible, maximum efforts should be made to expedite their delivery. Deliveries within a specified period of order must be adhered.

5. Two or more suppliers for each item may be engaged, so that dependence on one supplier is eliminated to safeguard against failure by one supplier.

6. Ordering quantities, re-order point and minimum stock level should be revised more frequently.

\section{B. Policies for B items}

1. The policies for B items in general are in between those for $\mathrm{A}$ and $\mathrm{C}$

2. Order for these items must be placed less frequently that for A items. It is recommended to place 3 to 6 orders per year for B items.

\section{Policies for $C$ items}

1. Since $\mathrm{C}$ items do not involve much capital tie up, the stock for such items may be kept liberally (i.e. stock for 6 months to one year).

2. Annual or 6 monthly orders should be placed to reduce paper work and ordering costs and to get advantage of quantity discounts for bulk purchase.

An example of $\mathrm{ABC}$ analysis of spare parts based on their value is shown in Table 4. 
Table 4 Suggested ABC analysis categories for various spare parts

\begin{tabular}{|r|l|r|r|c|}
\hline$\#$ & Description & unit price & $\begin{array}{l}\text { \% of } \\
\text { each }\end{array}$ & $\begin{array}{c}\text { ABC } \\
\text { Class }\end{array}$ \\
\hline 1 & Seal Kit & $1,015.52$ & 3.7 & C \\
\hline 2 & Stopper & 380.91 & 1.4 & C \\
\hline 3 & Ring Back up & 35.46 & 0.1 & C \\
\hline 4 & O- ring & 16.84 & 0.1 & C \\
\hline 5 & Spring & 235.23 & 0.9 & C \\
\hline 6 & Plate & 617.91 & 2.3 & C \\
\hline 7 & Disc & 451.69 & 1.7 & C \\
\hline 8 & Shaft Assy & $6,162.55$ & 22.6 & A \\
\hline 9 & Cone & 125.14 & 0.5 & C \\
\hline 10 & Bearing Assy & 787.83 & 2.9 & C \\
\hline 11 & Lock Nut & 16.84 & 0.1 & C \\
\hline 12 & Piston & $5,714.55$ & 21 & A \\
\hline 13 & Seal GP & 678.86 & 2.5 & C \\
\hline 14 & Hose & 15.3 & 0.1 & C \\
\hline 15 & Sleeve & 116.9 & 0.4 & C \\
\hline 16 & Stem & 455.45 & 1.7 & C \\
\hline 17 & V-belt seat & $1,087.80$ & 4 & B \\
\hline 18 & Valve brky & $1,625.00$ & 6 & B \\
\hline 19 & Filter & 347 & 1.3 & C \\
\hline 20 & Muffler & $7,350.00$ & 27 & A \\
\hline & Total Amount & $27,236.78$ & & \\
\hline
\end{tabular}

\section{EVALUATION OF WORKSHOP SITES}

The workshop site evaluation of the company was carried out considering the following criteria: the availability of area to absorb all activities, the potential for future expansion, easy access to water and electric supply and social and environmental interaction. From the evaluation criteria stated, currently the company's workshops are situated in a conductive environment so as to encourage maintenance and repair activities of its technical personnel. The workshop is not instituted in areas where noise causes serious social problems.

\section{EQUIPMENT REPLACEMENT LIFE}

The replacement problem is related to the replacement of an existing machine which has already been partially expended in service. The replacement problem is one of timing (when do you replace?) and selection (what machine?). The replacement life is defined as the remaining life of the present machine (the one now owned) which optimizes the advantage of the owner. The economics of ownership of the present machine must be compared with the economics of the ownership of a series of future machines which could replace it. The solution for the economic life of future replacement should be worked out first for each model of machine considered a potential replacement. Next the replacement life of the present machine must be found. Closer observation of the company's previous practice of decision making on equipment replacement life in the company showed that it was being done by subjective evaluation approaches like intuition. Absence of a properly defined equipment policy has led SS Construction to intuitive approach for equipment replacement decision. And it is recommended for the company to develop a future equipment and replacement plan at least for the coming five years. Forecasting future needs of 
equipment and vehicles depending on past activity has its own problems. The use of solutions methods based on minimization of cost and maximization of profit models was implemented to help in optimum decision making [1].

\section{ESTIMATING OWNING AND OPERATING COST}

Construction Equipment purchases are an investment that needs to be evaluated to determine which purchase has the better value for your business. Equipment performance and capacity to do the job are part of the decision process. However, the single purchase price cost is only one factor in the "real lifetime" equipment cost. Any purchase should be evaluated and take into account the loan factors, cost for maintenance and repairs, fuel consumption, insurance, and depreciation value to determine the "real lifetime cost" of the equipment being purchased [1].

As a guide to help for estimating "real lifetime" equipment costs before the next equipment purchase, the included "Cost of Ownership Template" spreadsheet (Figure 1) can give the users an example on how to estimate a construction equipment's "true" cost of ownership. This template breaks all costs into both fixed/owning and variable/operating cost per hourly amounts. Fixed costs are the interest and depreciation expense whereas variable costs are fuel, tires and maintenance costs. To use the Cost of Ownership template, the user will need to enter their equipment model cost parameters to calculate the true equipment cost of ownership. The template could be modified with user's own values. The user can change all the factors highlighted in yellow for their own calculations. While the white cells are optional and values of other colored cells should not be changed. Shown in Figure 1 is an example of the hourly owning and operating cost of CAT 444E BHL.

\begin{tabular}{|c|c|c|c|c|c|}
\hline \multicolumn{4}{|c|}{ Conditions: See descriptions below to enter your values } & Machine Model & CAT 44E BHL \\
\hline \multirow[t]{2}{*}{ Parameters } & ITEM & Units & \multirow[b]{2}{*}{ CAT 44E BHL } & 1. Owning Cost per Hour & \multirow[b]{2}{*}{4.39} \\
\hline & \multicolumn{2}{|l|}{ Machine Model } & & Depreciation (ERT) & \\
\hline A & Purchase price & USO & 109,712 & Interest (GRT) & 282 \\
\hline B & Purchase price, excluding tires! Tracks & & 105,294 & Machine Tax (HR) & 0.31 \\
\hline c & Depreciation time & years & & Insurance (IRT) & 157 \\
\hline$\frac{D}{E}$ & \begin{tabular}{|l} 
Residual value \\
Depreciation cost $[(B-D] C]$
\end{tabular} & \begin{tabular}{|c|}
$40 \%$ \\
per year
\end{tabular} & $\begin{array}{r}43,885 \\
8,773\end{array}$ & \multirow[t]{2}{*}{ TOTAL FIXED COST PERHR. } & 9.09 \\
\hline $\mathrm{F}$ & Interest & $\%$ & $9 \%$ & & \\
\hline G & Interest cost & per year & 5,642 & 2. Operating Cost per Hour & \\
\hline $\mathrm{H}$ & Machine tax & per year & 626.93 & Fuel $[\mathrm{J} \times \mathrm{K}]$ & 10.13 \\
\hline 1 & Insurance & per year & 3,135 & Oil, Grease, \& Filters $[1 \times \mathrm{m}]$ & 3.54 \\
\hline $\mathrm{J}$ & Fuel Cost & per gal & 2.25 & Tires ! Tracks (ndo) & 0.88 \\
\hline K & Fuel Cunsumption & gph & 4.50 & Repair \& Maintenance (PFR) & 4.74 \\
\hline L & Oil Cost & per q. & 158 & \multirow[t]{2}{*}{ TOTAL VARIABLE COST PERHR } & 19.29 \\
\hline M & Oil Consumption & at per $\mathrm{hr}$. & 2.25 & & \\
\hline $\mathrm{N}$ & Cost of a Set of Tiresi Tracks & & 4,418 & 3. Fixed + Variable Cost per Hour - Sub Total & 28.38 \\
\hline 0 & Lifetime of Tires I Tracks & hours & \begin{tabular}{r|}
5000 \\
9,484
\end{tabular} & \multirow[b]{2}{*}{ 4. Operator Cost per Hour [QRR] } & \\
\hline $\begin{array}{l}P \\
Q\end{array}$ & \begin{tabular}{|l} 
Repairs and Maintenance \\
Operator Cost
\end{tabular} & \begin{tabular}{|l|} 
per year \\
per year
\end{tabular} & $\begin{array}{|lr|}\$ & 9,484 \\
\$ & 40,000 \\
\end{array}$ & & 20.00 \\
\hline $\mathrm{R}$ & Operating Hours & per year & 2000 & & \\
\hline \multicolumn{3}{|c|}{ Note: Oil cost can be included as part of repair and maintenance. } & & TOTAL COST PER HOUR & 48.38 \\
\hline
\end{tabular}

Figure 1 Example of hourly owning and operating cost calculation template

The use of Owning and Operating cost estimation in comparing purchase of different equipment optimizes the advantage of the owner. That is the economics of ownership of the present machine must be compared with the economics of the ownership of a series of future machines which could replace it. The solution for the economic life of future replacement should be worked out first for each model of machine considered a potential replacement. Next the replacement life of the present machine must be found. 


\section{CONCLUSION}

Very good equipment management starts with proper equipment selection process. Therefore, a proper equipment selection process should always be followed which identify the equipment which identify the equipment that best fits the particular job requirements, at the same time achieving the lowest possible total equipment cost. Maximizing production and minimizing the operating and the initial investment cost gives lowest total equipment cost. It is important to note that purchase of equipment solely based on purchase price rarely results in lowest total equipment cost. In the process of equipment procurement the contractor should consider different options that could result in lower total equipment cost. Equipment management is the major factor that determines the profitability of most civil engineering projects like road and dam constructions. Where the major input of the project is equipment, and can mean the difference between job profit and loss, hence requires proper attention and working towards one goal achieving the lowest possible cost per hour or per ton of material moved.

This goal can be achieved if the company has selected the appropriate equipment for the job, operated it with care, maintained it properly and disposed it off at the right time.

The equipment and maintenance management of the company can be improved by establishing and implementing: Effective equipment and vehicle standardization; Equipment and vehicle replacement policy plan; Equipment and vehicle codification; Improving the maintenance planning and control system; Carrying out proper spare parts planning; Adoption of an appropriate strategy; Sound and effective organizational structure and manpower; Equipping the different workshops of the company with required work shop facilities and instrumentation tools; Developing effective and efficient maintenance system.

\section{REFERENCES}

[1] Caterpillar Performance Handbook, Edition 36, CATERPILLAR

[2] Construction Equipment and its Management, S.C. Sharma, Khanna Publishers. 2-B, Nath Market, Nai Sarak Delhi.

[3] Construction Equipment, Galperin, Mark Iseavich: Moskow: Mir Publishers, C1982

[4] Construction Equipment Policy, Douglas James: New York: MacGraw Hill, 1975

[5] Construction Equipment and its planning and application, Mahesh Barma: 3rd Edition. New Delhi.

[6] Levitt, Joel. The handbook of maintenance management. Industrial Press Inc., 2009.

[7] Al-Turki, Umar M. "Maintenance Planning and Scheduling." Handbook of Maintenance Management and Engineering. Springer London, 2009. 237-262. 